\title{
Anatomical variations of the coronary arteries and its correlation with digital anatomy
}

Presented at the 3rd World Congress of the UNESCO Chair for Teaching and Research in Digital Anatomy Paris Descartes at Egas Moniz University Institute - Almada, Portugal

\section{G. Prat, D. Costi, F. Scarpelli, C. Ruiz \& B. Lorea}

To cite this article: G. Prat, D. Costi, F. Scarpelli, C. Ruiz \& B. Lorea (2019) Anatomical variations of the coronary arteries and its correlation with digital anatomy, Annals of Medicine, 51:sup1, 57-58, DOI: $10.1080 / 07853890.2018 .1561932$

To link to this article: https://doi.org/10.1080/07853890.2018.1561932

$$
\text { 曲 Published online: } 28 \text { May } 2019 .
$$

\section{Submit your article to this journal ש}

Џ Article views: 80

Q View related articles $\llbracket$

View Crossmark data \lceil 
and academics have a better understanding of the three-dimensional disposition of the anatomical structure manifested by the academic acceptance of the online platform, based on the growing number of visitors.

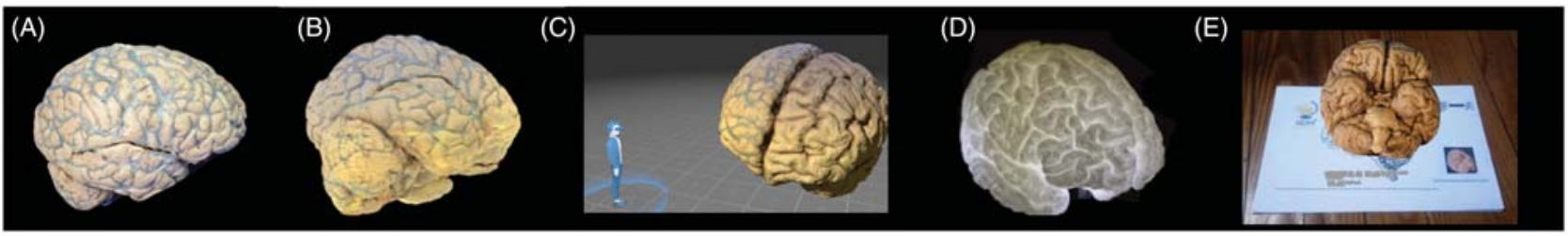

Figure 1. A) Brain photography B) Reconstruction 3D brain C) Virtual reality D) 3D printing flexible material E) Augmented reality. CONTACT Reyes González Juan Pablo reyes.g.jpablo@gmail.com

\title{
References
}

[1] Quinn MM, Smith T, Kalmar EL, et al. What type of learner are your students? Preferred learning styles of undergraduate gross anatomy students according to the index of learning styles questionnaire. Anat Sci Educ. 2018;11(4):358-365.

[2] Inzunza O, Caro I, Mondragón G, et al. 3D Impressions, New Technology that Supports Anatomical Teaching. Int J Morphol. 2015;33(3):1176-1182.

\section{Anatomical variations of the coronary arteries and its correlation with digital anatomy}

\author{
Presented at the 3rd World Congress of the UNESCO Chair for Teaching and Research in \\ Digital Anatomy Paris Descartes at Egas Moniz University Institute - Almada, Portugal
}

\author{
G. Prat ${ }^{a}$, D. Costi ${ }^{b}$, F. Scarpellic, C. Ruiz and B. Lorea ${ }^{c}$
}


Argentina; 'Subdirector of Laboratorio de Investigaciones Morfológicas Aplicadas, Facultad de Ciencias Médicas, Universidad Nacional de La Plata, Argentina; 'Teacher assistant of Laboratorio de Investigaciones Morfológicas Aplicadas, Facultad de Ciencias Médicas, Universidad Nacional de La Plata, Argentina

Introduction: The study, teaching and investigation of anatomy is entering in a new paradigm which includes technologies that allow the analysis of the human body from a whole different perspective. The aim of those who are working on this field is to merge classic anatomy with these new tools. In this paper, we will applicate their use to the study of the anatomical variations of the coronary arteries.

The anatomy of the coronary arteries [1-16] has been widely studied [17-20] due to their clinical relevance. The use of three-dimensional views of specific cases, as well as the 3D modelling are useful to understand the normal anatomy and its variations. Presented at the 3rd World Congress of the UNESCO Chair for Teaching and Research in Digital Anatomy Paris Descartes at Egas Moniz University Institute - Almada, Portugal.

Materials and methods: our team used 106 hearts, obtained by autopsy, that were protocolled with labels containing identification and demographics of each case. This pieces were preserved in formaldehyde $10 \%$ and dissected to individualize the main coronary arteries and their branches.

The creation of the 3D models followed a sequence of steps:

- Generating a raw model form cardiotomography and/or chest angiotomography. This models can also come from the slices of the Korean Visible Human (KVH) [21-24].

- Edition of the models utilizing different software's. A series of models can be united to create modules.

- Finally, they can be launched from platforms or 3D printed.

Results: the study revealed a huge disparity in the origin and distribution of the coronary arteries. The most frequent was on the birth of the branches from the left coronary artery [25] presenting multiple divisions, these were verified by imaging methods and angiography.

Knowing the normal coronary anatomy allows the creation and correction of the three-dimensional models, which makes 
them more reliable. Therefore, the models can be used for different porpoises such as teaching, investigation and they may have surgical uses.

Discussion and conclusions: although these new tools are startling which leads to a huge impact in users, they must not replace cadaveric anatomy. There should be a balance between both that allows the user to take out the best of each of them.

Dissecting, either virtually or classical, requires trained personal and their time. Having access to a huge data base, allows to create a potentially limitless number of models. Nevertheless, the personal should not only know anatomy but should also have informatics knowledge. Classical dissection is limited by the number of bodies and the means to preserve them. Employing this new tools for the study of the variation of the coronary arteries and its miocardical distribution is relevant not only for the resolution of pathological situations but also for educational porpouses [26-29].

Extrapolating these three-dimensional techniques to the whole body may seem ambitious, but the result should be impressive. The collaboration on the frame of the UNESCO chair of Digital Anatomy will allow its members to reach this goal.

CONTACT G. Prat lima.3d.unlp@gmail.com

\section{References}

[1] Williams P, Warwick R. Gray Anatomía. Salvat. 1985. Tomo 2, p. 734-42; 717-19.

[2] Latarjet M, Ruiz Liard A. Anatomía Humana. Panamericana. 2005. p. 937-41.

[3] Testut L, Latarjet A: Anatomía Humana. Salvat. 1956. p. 97-108.

[4] Rouviére H, Delmas A. Anatomía Humana, Descriptiva, Topográfica y Funcional. 1996. Vol II, p. 119-24.

[5] Anderson, J. Grant: Anatomía. 1986; Tomo1, p. 53-59. [10.1136/bmj.293.6538.53]

[6] Latarjet M, Ruiz Liard A. Anatomía Humana. 1991. Tomo 2, p. 1023-27.

[7] Casiraghi JC, Martinez JL, Ravetta MC, et al. Anatomía del Cuerpo Humano Funcional y Quirúrgica. 1982. Tomo 2, p. 212-14.

[8] Bouchet A, Cuilleret J. Anatomía Descriptiva, Topográfica y Funcional. 1985. Tórax, p.183:91.

[9] Galli E. Corazón. Editorial Lopez, Buenos Aires. 1933.

[10] Anderson R. Beccker: Atlas Anatomía Cardíaca. Editorial Doyma, Barcelona. 1981. p. 422-53; 622-23; 816-17.

[11] Lockhart R, Hamilton G. Anatomía Humana. Panamericana 1965. p. 589:91.

[12] Orts Llorca F. Anatomía Humana. Editorial Medica. Barcelona, 1952. Tomo III p. 40:52.

[13] Rohen Y. Atlas Fotográfico de Anatomía Humana. Ed.Doyma, Barcelona 1994. p. 241-43.

[14] Favaloro R. Tratamiento quirúrgico de la arteriosclerosis coronaria. Ed. Intermedica. Bs.As 1973

[15] Blake HA, Manion WC, Mattingly TW, et al. Coronary artery anomalies. Circulation. 1964;30:927-940.

[16] Landolt CC, aderson JE, Zorn-Chelton S, et al. Importance of coronary artery anomalies in operatons for congenital hart disease. Ann Thoraci Surg. 1986;41:351-355.

[17] Ogden JA. Congenital anomalies of the coronary arteries. An J Cardiolo. 1970;25:474-479.

[18] Ramesh MG, ljaz A, Manish U, et al. Origin of all major coronary arteries from left sinus of Valsalva as a common coronary trunk: single coronary artery. Angiology. 2004;55:103-105.

[19] Surucu HS, Karhan S, Tanyeli E. Branching pattern of the left coronary artery and a important branch. Saudi Med J. 2004;25:177-181.

[20] Silverman KL, Bulkley BH, Hutcins GM. Anomalous left circumflex coronary: normal variant of uncertain clinical and pathologic significance. Am j Cardiol. 1978;41:1311-1314. doi:10.1016/0002-9149(78)90891-3

[21] Ackerman MJ. The Visible Human project. A resource for education. Acad Med. 1999;74(6):667-670.

[22] Spitzer V, Whitlock D. The Visible Human dataset. The anatomical platform for human simulation. Anat Rec. 1998;253(2):49-57.

[23] Park JS, Chung MS, Hwang SB, et al. Visible Korean Human: Improved serially sectioned images of the entire body. IEEE Trans Med Imaging. 2005;24(3):352-360.

[24] Park HS, Choi DH, Park JS. Improved sectioned images and surface models of the whole female body. Int J Morphol. 2015;33(4):1323-1332. doi:10.4067/S0717-95022015000400022

[25] Brandt B, Martins JB, Marcus ML. Anomalous original of the coronary artery from the left sinus of Valsalva. N England J Med. 1983;309:596.

[26] Liberthson RR, Dinmore RE, Bharati S. Aberrant coronary artery origin fron the aorta: diagnosis and clinical significance. Circulation. 1974;50:774-779. doi:10.1161/01.CIR.50.4.774

[27] Yamanaka O, Hobbs RE. Coronary artery anomalies in 126.595 patients undergoing coronary catheterism. Cathet Cardiovasc Diagn. 1990;21:28-40. doi:10.1002/ccd.1810210110

[28] Page HL Jr, Engel HJ, Campbell WB, et al. Anomalous origin of the left circumflex coronary artery: recognition, angigrafhic demonstration and clinical significance. Circulation. 1974;50:68-73.

[29] Taylor AJ, Rogan KM, Virmani R. Sudden cardiac death associated with isolated congenital coronary artery anomalies. JAM Coll Cardiol. 1992;20:640-647. 